\title{
ArcheoSciences
}

Revue d'archéométrie

\section{In-situ examination and analysis of the gold jewellery from the Phoenician tomb of Kition (Cyprus)}

Examen et analyse in situ d'orfèvrerie en or de la tombe phénicienne de Kition (Chypre)

\section{Maria Filomena Guerra and Thilo Rehren}

\section{OpenEdition}

\section{Journals}

\section{Electronic version}

URL: https://journals.openedition.org/archeosciences/2148

DOI: 10.4000/archeosciences. 2148

ISBN: 978-2-7535-1598-7

ISSN: $2104-3728$

Publisher

Presses universitaires de Rennes

\section{Printed version}

Date of publication: 31 December 2009

Number of pages: 151-158

ISBN: 978-2-7535-1181-1

ISSN: 1960-1360

Electronic reference

Maria Filomena Guerra and Thilo Rehren, "In-situ examination and analysis of the gold jewellery from the Phoenician tomb of Kition (Cyprus)", ArcheoSciences [Online], 33|2009, Online since 10 December 2012, connection on 28 January 2022. URL: http://journals.openedition.org/archeosciences/2148 DOI: https://doi.org/10.4000/archeosciences.2148 


\title{
In-situ examination and analysis of the gold jewellery from the Phoenician tomb of Kition (Cyprus)
}

\author{
Examen et analyse in situ d'orfevrerie en or \\ de la tombe phénicienne de Kition (Chypre)
}

\author{
Maria Filomena Guerra* and Thilo Rehren**
}

\begin{abstract}
The Phoenician tomb discovered in Kition in 1998 yielded some of the most impressive gold jewellery items recovered by archaeological excavations in Cyprus. Seal finger-rings, lunate earrings, necklace pendants, bracelets and a richly decorated elbow fibula exemplify the goldsmith's skill in the $8^{\text {th }}-7^{\text {th }}$ century BC. The aim of this work is to describe and illustrate the goldsmith's techniques with low magnification micrographs and to determine the variety in composition of the gold alloys used in the manufacture of 25 items. The study, integrated in the European project AUTHENTICO, was carried out at the National Museum of Archaeology of Nicosia with a portable video camera equipped with a zoom and a handheld XRF spectrometer.

Résumé : Parmi les objets d'orfevrerie les plus impressionnants livrés par les fouilles archéologiques menées à Chypre, se trouvent ceux découverts en 1998 dans la tombe phénicienne de Kition. Bagues à sceau, boucles d'oreille, pendants de colliers, bracelets et une fibule à l'arc coudé richement décorée, mettent en évidence la virtuosité de l'orfevre au VIIT-VIT siècle av. J.-C. Le but de ce travail est de décrire et illustrer les techniques employées par l'orfevre et de déterminer la variété des alliages en or employés. L'étude analytique a été réalisée dans le cadre du projet européen AUTHENTICO, au Musée national d'archéologie de Nicosie, à l'aide d'une camera vidéo portable équipée d'un zoom et d'un analyseur de fluorescence X portable miniaturisé.
\end{abstract}

Keywords: Jewellery, analysis, Kition, Phoenician, gold.

Mots-clés : Orfevrerie, analyse, Kition, phénicien, or.

\section{INTRODUCTION}

The Phoenician tomb M $\Lambda$ A 1742, with two chambers and a step dromos excavated near Larnaca in 1998 (Hadjisawas, 1999), delivered Phoenician pottery and jewellery of high quality and exceptional iconography described in a publication by Flourentzos and Vitobello in this issue of ArcheoSciences. Similar costume jewellery was found in other Phoenician sites of the Mediterranean (Carpenter, 1958).

The aim of this work is to describe the different steps of production of some of the 25 gold items found in the tomb and to determine the base alloys used in the manufacture of their different parts. Very few analytical studies address Cypriot gold jewellery, and the number of gold objects generally found in the archaeological excavations from before

* Laboratoire du Centre de Recherche et de Recherche et de Restauration des Musées de France, UMR171 CNRS - 14, quai François-Mitterrand, 75001 Paris, France. (maria.guerra@culture.gouv.fr)

** UCL Institute of Archaeology-31-34 Gordon Square, London WC1H 0PY, United Kingdom. (th.rehren@ucl.ac.uk) 
the Late Cypriot period is small, most likely due to the absence of gold sources on the island (Maxwell-Hyslop, 1971).

The jewellery finds in Cyprus are often stylistically connected to Syria-Palestine - ropes of twisted wire, rosettes, granulated triangles, etc. - and Minoan-Mycenae - granulations (Lilyquist, 1993), pins, pennanular and twisted earrings, etc. - gold work. The rich Late Cypriot II finds of Enkomi (Myres, 1914; Murray et al., 1970; Åström, 1972) demonstrate the existence of relations with Tell Ajjul and Meggido in Palestine, with Ras Shamra in Syria, with Troy in Greece, etc.

From the $8^{\text {th }}$ to the $7^{\text {th }}$ century BC, the Mesopotamian influence on the various jewellery working centres of the Levant persists (Maxwell-Hyslop, 1960). The excavations of Amathus, Salamis and Kition in Cyprus show that rich Phoenician goods reached Cyprus during this period (Bikai, 1989).

The jewellery items from the Kition tomb that are most representative of the relation of Cyprus with other Mediterranean civilisations are the solid lunate earrings (Fig. 1a) and the elbow triangular fibula (Fig. 1b); see also the contribution by Flourentzos and Vitobello in this issue.

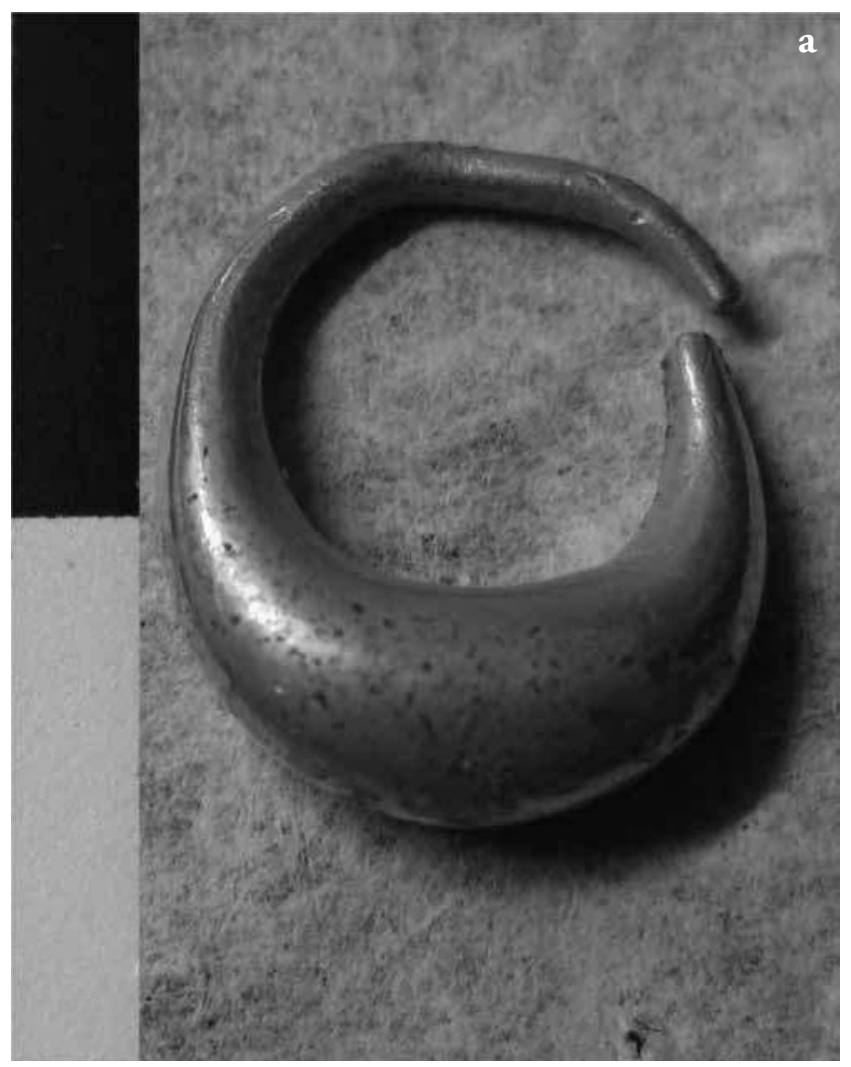

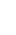

The main focus of this paper is on the massive gold elbow triangular fibula of Kition, decorated with three rosettes in inlaid cloisonné and hanging down chains with lotus flower-shaped bells. The arrival of this type of fibula in the Mediterranean region is related to the expansion of Mycenaean trade, which brought new types of artefacts to Cyprus towards the end of the $13^{\text {th }}$ century BC (Stronach, 1959): along these lines, we can refer to the chamber tomb with a dromos finds from Enkomi (Courtois, 1982), Kato Alonia/Kouklia (Karageorghis, 1963), Amathus (Karageorghis, 1988), Ayios Athanasios (Karageorghis, 1986) in Kourakou/Nicosia (Karageorghis, 1965), and Alassa-Kandou/Limassol (Karageorghis, 1988). Usually in bronze, triangular bow (or 'knee' or 'elbow') fibulae are very popular from the $8^{\text {th }}$ century $\mathrm{BC}$ to the $1^{\text {st }}$ century AD in Cyprus, Egypt and Persia, but also in France (Mohen et al., 1971), Portugal (Ponte, 1999), the Caucasian regions (Muscarella, 1965) and Spain (Chamorro, 1987).

The fibula from Kition has inlaid cloisonné rosettes and flower bell-shaped pendants. The use of decorative rosettes dates back to the $3^{\text {rd }}$ millennium BC in Mesopotamia and Egypt (Tait, 2006; Cline and O'Connor, 2006), and can
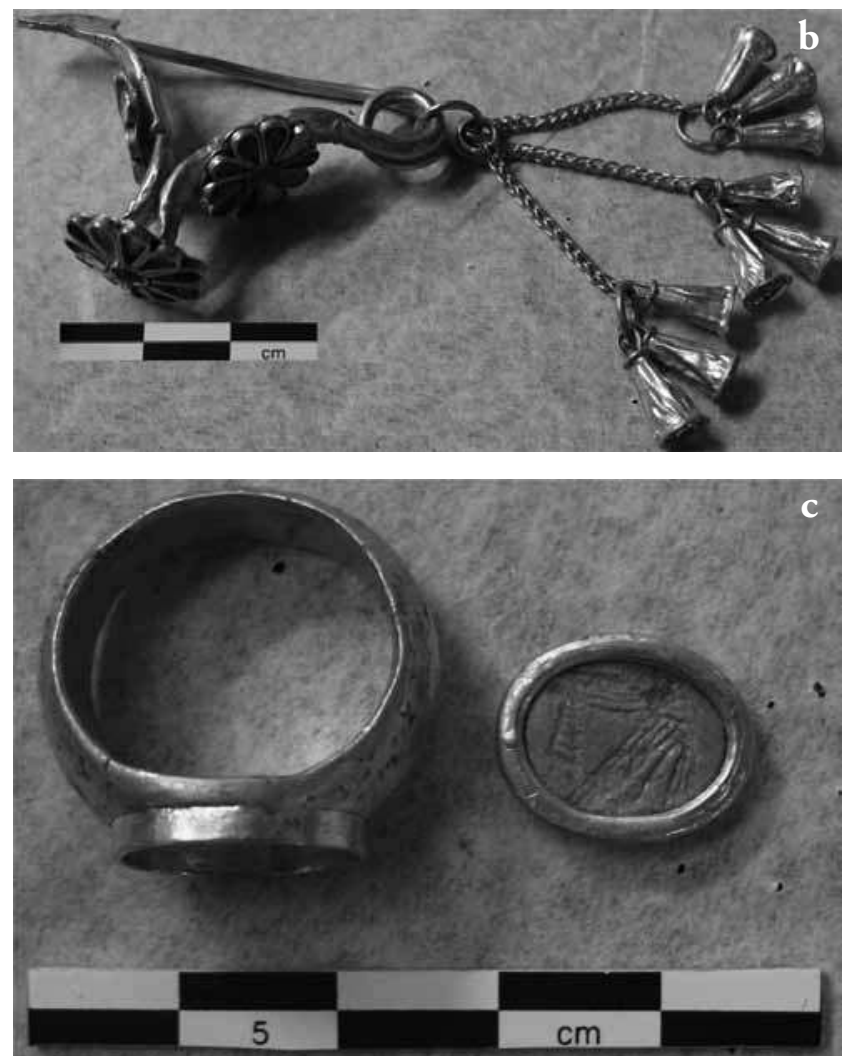
also be seen in a pin from Troy (Schliemann, 1880). Those in inlaid cloisonné with red and blue glass paste can be seen in the $15^{\text {th }}$ century BC Egyptian Queen Iahhotep's collar (Collective, 2004) and in the Mycenaean finger ring from Vapheio (Collective, 1988). The use of chains and bells is common in Phoenician jewellery, and examples of it are represented by the earrings from Camyrus (Salzmann, 1863), Tharros (Acquaro, 1984) and Liomilya/Kouklia (Brunet and Moretti, 1990).

Solid lunate earrings in gold, bronze and silver, characterized by a solid crescentic body from one end of which the pin for suspension rises, were found as early as the $3^{\text {rd }}$ millennium $\mathrm{BC}$ at $\mathrm{Ur}$ and took various forms during the Iron Age (Hawkes, 1961). In this context, we are reminded of those from Ajjul $\left(10^{\text {th }}\right.$ century BC), Nimrud $\left(7^{\text {th }}\right.$ century BC) and Tell Fara $\left(11^{\text {th }}-10^{\text {th }}\right.$ century BC) (Curtis and Maxwell-Hyslop, 1971). In Cyprus, leech-shaped earrings - an elongated version of the tapered hoop (Higgins, 1980), but with elongated loop - were found in Kouklia (Catling, 1968), Mesayitonia - Limassol (Karageorghis, 1963b), and in Amathus (Karageorghis, 1979).

Other finds from the tomb include a necklace with stone inlay and a bracelet with a scarab inlay, both with delicate loop-in-loop wirework; several beads or pendants made entirely from gold, some with fine filigree work, and several stone or faience beads with gold finials; and several metal signet rings with cartouche-shaped bezels containing faience, glass or stone inlays. A full presentation of the finds is in preparation (Flourentzos forthcoming).

\section{Results}

For the study of the jewellery items from Kition, we used a high resolution Flexia video microscope with a zoom reaching $x 80$, a built-in LED illumination and a Bersoft image measurement software. The analysis of the alloys was carried out with a handheld XRF spectrometer, Innov-X Systems Model Alpha 8000 LZX, with a silver tube, and operating at $40 \mathrm{kV}, 29 \mu \mathrm{A}$, and employing a quantification method optimised for alloys.

The XRF analyses were carried out with an acquisition time of $25 \mathrm{sec}$, resulting in lifetimes of 19-22 sec. Precision and accuracy were tested by repeated analyses of a range of both certified and internal reference materials with compositions comparable to the gold alloys studied (Table 1). Precision was found to be always better than 5\% relative, and accuracy was typically better than $10 \%$ relative. The majority of the results reported are averages of 2-3 measurements, and they have been normalised to $100 \mathrm{wt} \%$. In

\begin{tabular}{|c|c|c|c|c|}
\hline & & Au wt $\%$ & Ag wt\% & $\mathrm{Cu}$ wt $\%$ \\
\hline \multirow{2}{*}{1814 coin } & \multirow{2}{*}{$\begin{array}{l}\text { given } \\
\text { measured }\end{array}$} & balance & 4.8 & 4.3 \\
\hline & & 90.8 & 4.3 & 4.9 \\
\hline \multirow{2}{*}{ A1 EJTN } & \multirow{2}{*}{$\begin{array}{l}\text { given } \\
\text { measured }\end{array}$} & balance & 5.1 & 2.2 \\
\hline & & 92.4 & 6.1 & 1.5 \\
\hline \multirow{2}{*}{ A2 EJTN } & \multirow{2}{*}{$\begin{array}{l}\text { given } \\
\text { measured }\end{array}$} & balance & 20.5 & 4.2 \\
\hline & & 75.1 & 21.2 & 3.8 \\
\hline \multirow{2}{*}{ E2 EJTN } & \multirow{2}{*}{$\begin{array}{l}\text { given } \\
\text { measured }\end{array}$} & balance & 41.5 & 0.5 \\
\hline & & 59.6 & 39.6 & 0.7 \\
\hline
\end{tabular}

Table 1: Internal reference analyses by XRF.

Tableau 1 : Résultats des analyses de standards d'or par FX.

some instances, low concentrations of iron were found, but disregarded as potential surface contaminations.

\section{Earrings}

The five solid gold lunate-shaped earrings with a bent over the hoop are cast close to shape. The hoop is hammered to form the crooked pin (Fig. 2), and the other end is finished by polishing. The compositions of the gold alloys used in the fabrication of these five items have silver contents ranging from about $11 \%$ to $21 \%$, and copper contents from about $1 \%$ to just over $2 \%$ (see results on Table 2). Thus, despite their stylistic and technical similarity, and internal consistency, they are made from a rather wide range of gold alloys. Interestingly, the silver to copper ratio is about 10 for all analyses. The variety of the Phoenician gold alloys was shown for the Gadir region by Ortega-Feliu et al. (2007).

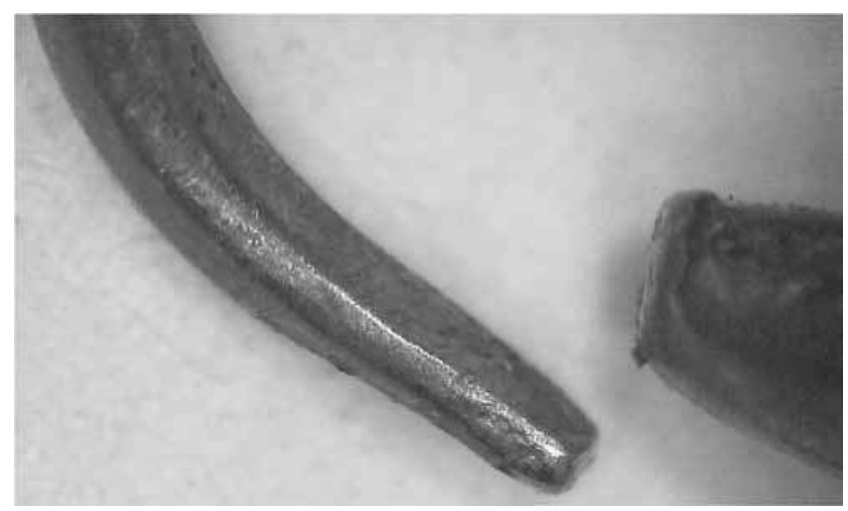

Figure 2: Both ends of earring 1742/24, with the hammer facets on the surface typical of hammering.

Figure 2: Les deux terminaux de la boucle d'oreille 1742/24 avec les facettes typiques du martelage. 


\begin{tabular}{|c|c|c|c|c|}
\hline & region of analysis & Au wt $\%$ & $\mathrm{Ag} \mathrm{wt} \%$ & $\mathrm{Cu} w \mathrm{wt} \%$ \\
\hline \multicolumn{5}{|l|}{ Earrings } \\
\hline $1742 / 21$ & body & 83.8 & 14.5 & 1.7 \\
\hline $1742 / 22$ & body & 78.7 & 19.0 & 2.3 \\
\hline $1742 / 23$ & body & 77.3 & 20.7 & 2.0 \\
\hline $1742 / 24$ & body & 88.2 & 10.9 & 0.9 \\
\hline $1742 / 25$ & body & 77.9 & 20.0 & 2.1 \\
\hline \multirow{7}{*}{ Fibula $1742 / 20$} & 2 bells on pendant 1 & 82.7 & 15.8 & 1.5 \\
\hline & 2 bells on pendant 2 & 81.7 & 16.0 & 2.3 \\
\hline & 2 bells on pendant 3 & 82.3 & 15.4 & 2.3 \\
\hline & 3 chains jointly & 82.0 & 16.4 & 1.6 \\
\hline & spiral & 84.1 & 14.9 & 1.0 \\
\hline & shield of pin & 82.6 & 16.6 & 0.9 \\
\hline & side of flower & 83.3 & 15.7 & 1.0 \\
\hline \multicolumn{5}{|l|}{\begin{tabular}{|l|} 
Finger-rings \\
\end{tabular}} \\
\hline $1742 / 1475$ & hoop & 97.7 & 2.1 & 0.2 \\
\hline $1742 / 1476$ & hoop & 97.9 & 1.9 & 0.2 \\
\hline $1742 / 1477$ & hoop & 99.9 & 0.0 & 0.2 \\
\hline
\end{tabular}

Table 2: Results obtained by XRF for the lunate earrings, the elbow triangular fibula, and the signet finger-rings.

Tableau 2 : Résultats obtenus par FX pour les boucles d'oreille en lune, pour la fibule triangulaire coudée et pour les bagues à sceau.

\section{The fibula}

The massive gold elbow triangular-shaped fibula is decorated with rosettes in cloisonné, inlaid with red and blue glass paste. The plain triangular pin is approximately $2 \mathrm{~mm}$ in diameter and shaped by casting and hammering - one soldering point on the top (Fig. 3a) reinforces the item. It is decorated with engraved lines produced with a triangular burin. The cloisonné rosettes consist of a base gold foil, cut and polished on the borders, where strips around $400 \mu \mathrm{m}$ thick and 1000 to $1200 \mu \mathrm{m}$ in length, cut with a chisel, are hard-soldered. We note that this technique was found previously in Tartesic (Ontalba-Salamanca et al., 2001) and Phoenician (Ortega-Feliu et al., 2007) jewellery. The internal surfaces of the petals are scratched (Fig. $3 \mathrm{~b}$ ), potentially to improve the adherence of the glass paste, either directly, when applied as a hot semi-molten mass, or to provide more grip for any adhesive that might have been used if the inlays were applied cold. On the back-side of the gold foil, one wire covers the joining with the pin.

The loop-in-loop chains are obtained with strip-twisted wires of 450-500 $\mu \mathrm{m}$ in diameter (Fig. 3c), and the bells are made of rolling gold foils in repoussé adorned with wires of about $600 \mu \mathrm{m}$ in diameter (Fig. 3d). The suspension rings are of about $700 \mu \mathrm{m}$ in diameter, and the round ring of which different pendants are suspended has a diameter of about $950-1000 \mu \mathrm{m}$.
All the elements of the fibula were produced with a relatively similar base alloy, containing 82 to $83 \mathrm{wt} \%$ gold, 15 to $16 \mathrm{wt} \%$ silver, and 1 to just over $2 \mathrm{wt} \%$ copper. Within this already relatively narrow range two discrete subgroups emerge, with their main difference residing in the copper content. The chains and bells forming the pendants are made from an alloy containing a slightly higher copper content $(1.5$ to $2.3 \mathrm{wt} \% \mathrm{Cu}$ ), while the body of the fibula has consistently only $1 \mathrm{wt} \%$ copper. In contrast to the earrings, where the copper and silver contents were directly correlated, no such correlation is apparent here. The silver content is almost the same for all parts of the fibula, while the copper content differs by a factor of two between the pendant parts and the main body of the fibula. Whether the different concentrations of copper were used in order to change the hardness, or simply reflect the assemblage of parts obtained from different sources or even workshops, is impossible to decide on the basis of these analyses alone.

The remaining gold artefacts were also studied and a full publication is forthcoming. Here, it may suffice to say that the workmanship is consistent with the details described above for the fibula and earrings, and that the majority of the other items are made from gold of similar or even baser composition than the one used for the fibula pendant parts, that is to say of gold with 15 to $25 \mathrm{wt} \%$ silver and 2 to $3 \mathrm{wt} \%$ copper. The bracelet with scarab and the necklace with stone inlay are made from higher-quality gold, with 15 

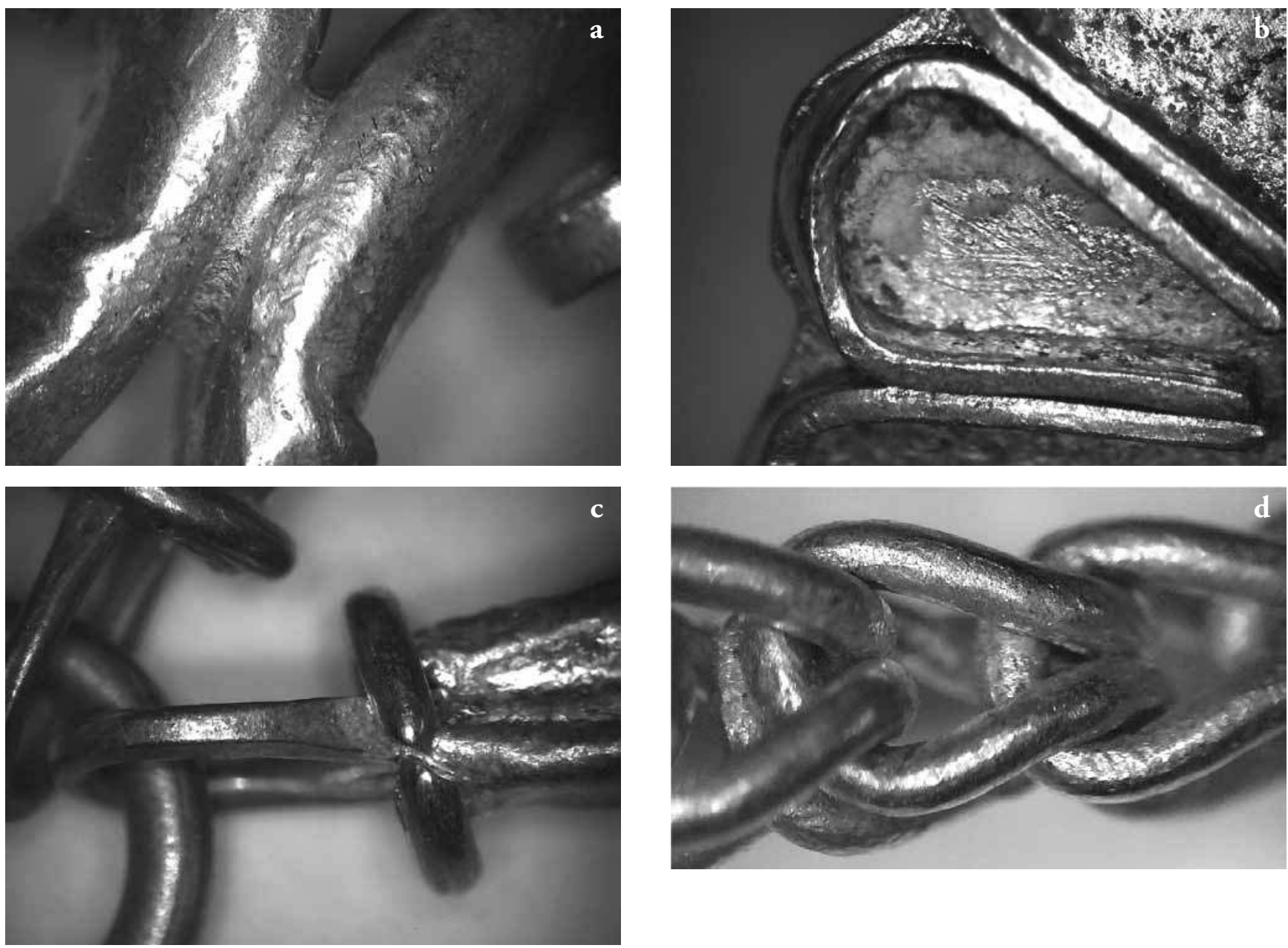

Figure 3: (See colour plate) The fibula construction: (a) the two branches are hard-soldered; (b) cloisonné rosette - the internal surfaces of the petals are scratched; (c) lotus flower bells hoop; (d) the loop-in-loop chains.

Figure 3 : (Voir planche couleur) La construction de la fibule: (a) les deux branches soudées par brasure; (b) la rosette en cloisonné-les surfaces internes sont grattées; (c) les anneaux des cloches en forme de fleur de lotus; (d) les chaînes de suspension.

to $18 \mathrm{wt} \%$ silver and 1 to $2 \mathrm{wt} \%$ copper. Remarkably, the three signet finger-rings with cartouche-shaped bezels (Fig. 4 shows that the internal surface of the bezel is also scratched) form a compositionally very different group, being made of high-carat gold. Their silver content is consistently below $2 \mathrm{wt} \%$, and copper below $0.5 \mathrm{wt} \%$ in almost all analyses (Table 2).

The microscopic study of the objects did not reveal any hard grey inclusions in the gold, and the XRF analyses did not indicate the presence of platinum group elements in any of the analysed areas. Tin was found only in one of the XRF spectra, in one of the finger rings, at a level too low to reliably quantify.

\section{Discussion}

The technical study of the finds shows the use of casting and hammering as well as of hard-soldering for the production of the jewellery from the Kition tomb. All these techniques could be identified on Phoenician, Punic and Tartesic jewellery. Similarly, the techniques of decoration by application of flower bells, glass paste in cloisonné, loopin-loop chains, ropes made with twisted wires, etc. are also expected for this type of jewellery.

Traces of use-wear could be seen on the surface of all objects. This indicates that the objects were used for some period of time, and not only made for funerary purposes. Phoenician jewellery is frequently accepted as the precursor of Etruscan gold work; however, the diameters of the wires, 
the thickness of the gold foils, the wire and filigree patterns, and so forth seen in our objects are far from the delicate craftsmanship of Etruscan gold.

Chemically, there appear to be two different compositional groups represented among the gold objects; both are consistent with unalloyed native gold. With the exception of the three finger rings, the silver content varies from 15 to $25 \mathrm{wt} \%$, while the copper content is mostly between 1 and $2.5 \mathrm{wt} \%$. The silver content is what one would expect from mined natural gold, neither refined nor alloyed. Hough et al. (2009) report typical silver values for primary or hypogene gold of 5 to $20 \mathrm{wt} \%$, only occasionally exceeding $50 \mathrm{wt} \%$. Analytical data for geological gold suggest that most individually analysed gold particles have between 10 and c. $40 \mathrm{wt} \%$ silver, but almost always less than $1 \%$ copper (e.g. Chapman and Mortensen, 2006). However, most gold deposits also have small amounts of copper and silver minerals associated, and during the concentration of the gold from the mined rock ore, some of these heavy minerals will inevitably be retained in the resulting concentrate (see e.g. Hauptmann and Klein, 2009) in this volume of ArcheoSciences). Thus, during the smelting of the gold concentrate, this copper will be partly alloyed into the bullion, resulting in the slightly elevated levels reported here. In modern gold mining, using advanced mineral concentration methods and aiming for complete gold recovery, this results in much higher silver and copper concentrations in the raw bullion than are found in the individual gold grains from the same deposit.

Gold obtained from secondary placer deposits, in contrast, differs systematically in its composition from the gold in the primary deposits. During transport, the silver content of the primary gold is more and more reduced due to leaching (e.g. Krupp and Weiser, 1992; Knight et al., 1999; Hough et al., 2009), while the primary accessory minerals such as chalcopyrite and various silver minerals are quickly dissolved and hence effectively separated from the placer gold. Depending on the make-up of the geological hinterland of the river system from which the placer gold is panned, it can be enriched in platinum group elements (Meeks and Tite, 1980) even though gold and platinum rarely occur together in the same primary deposits. This is noteworthy for example in the gold from Sardis in Turkey (Meeks et al., 1996). Thus, placer gold will have less copper and lower silver on average than freshly mined gold, but potentially more PGE inclusions.

It is of course possible that the copper was added intentionally; the effects of even small amounts of copper on hardness are relatively high, due to the c $12 \%$ difference in atomic radii between gold and copper (Hough et al., 2009), while the effect on the colour is probably too low to have

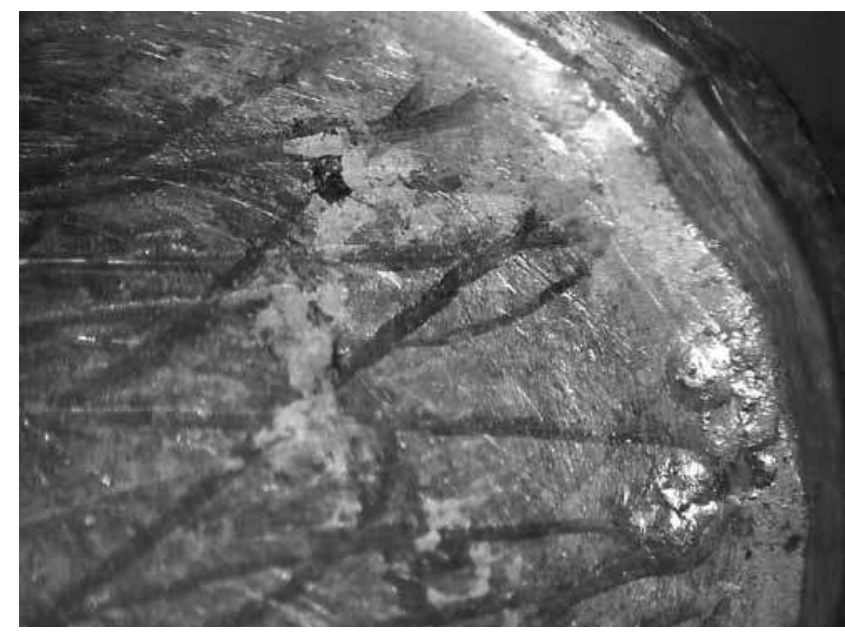

Figure 4: The bezel of gold signet finger-ring 1742/1476: the internal surfaces of the bezels are scratched.

Figure 4: Le chaton de la bague à sceau 1742/1475: les surfaces internes du chaton ont été grattees.

been manipulated at such a fine level. Equally, it is possible that a batch of gold of a certain composition, and hence property, was chosen for a specific task, that is, a coppercontaining gold might have been preferred for objects that could exploit the improved hardness, such as thin sheet or wire making.

The three finger rings with their exceptionally high gold content of $98 \%$ or more form a very distinct group among the material excavated from the tomb; such a highpurity gold could indicate that it was refined and parted. However, current knowledge suggests that gold parting, that is the intentional removal of silver from native gold, was only introduced sometime in the mid- $1^{\text {st }}$ millennium $\mathrm{BC}$, in the context of the development of gold coinage in Sardis (Ramage and Craddock, 2000). Therefore, it is more likely that these rings were made from a particular gold source rather than from fully refined gold. Such pure gold most likely comes from a secondary or supergene deposit. Supergene gold forms under specific environmental conditions, such as the warm and humid paleoclimate that resulted in the lateritic soils of SE Europe and Turkey to form (Herrington et al., 2007). During lateritic weathering, primary argentiferous gold is temporarily brought into solution and then re-deposited as almost pure gold grains and nuggets, typically containing $2 \mathrm{wt} \%$ silver or less, and nearly no copper (Freyssinet et al., 1989, 2005; Hough et al., 2009). On balance, we assume that the finger rings were made from supergene gold rather than from gold that had been subjected to parting. 


\section{Conclusion}

The investigation of the Kition jewellery has given detailed insight into the manufacturing skills of the Phoenician jewellers producing these outstanding objects, as well as showing their competent selection of natural gold alloys for different applications. The level of craftsmanship is consistent with the best of the known jewellery from the period, and the assumption that these objects were made by Phoenicians with some Egyptianizing influence on the iconography and design. While we can not exclude the possibility that the low copper concentrations in the gold containing 15 to 20 wt $\%$ silver are due to the alloying of a purer gold with a copper-silver alloy, we believe that the compositional characteristics of mined gold and supergene gold, respectively, are sufficient for an interpretation based on selection of natural gold varieties, rather than active manipulation of the gold composition.

\section{References}

ACQuaro, E., 1984. Sardegna Archeologica, Studi e Monumenti 2, arte e cultura punica in sardegna, Carlo Delfino editore.

Åström, L., 1972. The Swedish Cyprus Expedition Vol. IV/1D. The Late Cypriote Bronze Age. Other arts and crafts Lund.

BIKAI, P.M., 1989. Cyprus and the Phoenicians. The Biblical Archaeologist 52(4): 203-209.

Brunet, M. and Moretti, J.-C., 1990. Chronique des fouilles et découvertes archéologiques à Chypre en 1989. Bulletin de correspondance hellénique 114(2): 941-985.

Catling, H.W., 1968. Kouklia : Evreti Tomb 8. Bulletin de correspondance hellénique 92/1: 162-169.

Carpenter, R., 1958. Phoenicians in the West, American J. Archaeology 62/1: 35-53.

Chamorro, J.G., 1987. Survey of Archaeological Research on Tartessos. American J. Archaeology 91/2: 197-232.

Chapman, R.J. and Mortensen, J.K., 2006. Application of microchemical characterization of placer gold grains to exploration for epithermal gold mineralization in regions of poor exposure. Journal of Geochemical Exploration 91: 1-26.

Collective, 2004. Pharaon, Paris, Institut du Monde Arabe/ Flammarion.

Collective, 1988. Das Mykenische Hellas, Kulturministerium Griechenlands/ICOM - Freie Universität Berlin, Athens.

Courtois, J.-C., 1982. L'activité métallurgique et les bronzes d'Enkomi au Bronze Récent, in J.D. Muhly and V. Karageorghis eds. Early metallurgy in Cyprus, 4000-500 BC, Nicosia, 155-175.

Curtis, J.E. and Maxwell-Hyslop, K.R., 1971. The gold jewellery from Nimrud, Iraq 33/2: 101-112.
Cline, E.H. and O'Connor, D.B., 2006. Thutmose III: a new biography, The University of Michigan Press.

Freyssinet, Ph., Zeegers, H. and Tardy, Y., 1989. Morphology and geochemistry of gold grains in lateritic profiles of southern Mali. Journal of Geochemical Exploration 32: 17-31.

Freyssinet, Ph., Butt, C.R.M., Morris, R.C. and Piantone, P., 2005. Ore-forming processes related to lateritic weathering, Economic Geology 100th Anniversary Volume, 681-722.

Hadjisawas Sophokıis, 1999. Chronique des fouilles et découvertes archéologiques à Chypre en 1998, Bulletin de correspondance hellénique 123(2): 599-633.

Hauptmann, A. and Kuein, S., 2009. Bronze Age gold in Southern Georgia. ArcheoSciences, 33.

Hawkes, C., 1961. Gold ear-rings of the Bronze Age East and West, Folklore 72/3: 438-474.

Herrington, R., Boni, M., Skarpelis, N. and Large, D., 2007. Palaeoclimate, weathering and ore deposits - a European perspective. Proceedings of the Ninth Biennial SGA Meeting, Dublin, 1373-1376.

Higgins, R., 1980. Greek and Roman Jewellery, $2^{\text {nd }}$ ed., London.

Hough, R., Butt, C. and Fischer-Bühner, J., 2009. The crystallography, metallography and composition of gold. Elements 5: 297-302.

Karageorghis, V., 1963. Chronique des fouilles et découvertes archéologiques à Chypre en 1963, Bulletin de correspondance hellénique 88(1): 289-379.

KarageOrghis, V., 1963b. Une tombe de guerrier à Palaepaphos, Bulletin de correspondance hellénique 87(1): 265-300.

Karageorghis, V. 1965. Chronique des fouilles et découvertes archéologiques à Chypre en 1964, Bulletin de correspondance hellénique 89(1): 231-300.

Karageorghis, V., 1979. Chronique des fouilles et découvertes archéologiques à Chypre en 1978, Bulletin de correspondance hellénique 103(2): 671-724.

Karageorghis, V., 1986. Chronique des fouilles et découvertes archéologiques à Chypre en 1985, Bulletin de correspondance hellénique 110(2): 823-880.

Karageorghis, V., 1988. Chronique des fouilles et découvertes archéologiques à Chypre en 1987, Bulletin de correspondance hellénique 112(2): 793-855.

Knight, J.B., Mortensen, J.K. and Morison, S.R., 1999. The relationship between placer gold particle shape, rimming and distance of fluvial transport as exemplified by gold from the Klondike, Yukon Territory, Canada. Economic Geology 94: 635-648.

KRUPP, R.E. and WeISER, T., 1992. On the stability of gold-silver alloys in the weathering environment. Mineralium Deposita 27: 268-275.

LILYQUisT, C., 1993. Granulation and glass: chronological and stylistic investigations at selected sites, ca. 2500-1400 B. C. 
E., Bulletin of the American Schools of Oriental Research 90-91: 29-94.

MaXwell-Hyslop, K.R., 1960. The Ur jewellery, Iraq 22: 105115.

Maxwell-Hyslop, K.R., 1971. Western Asiatic Jewellery c 3000612 B.C., London, Methuen \& Co.

Meeks, N. and Tite, M.S., 1980. The analysis of platinum-group element inclusions in gold antiquities. Journal of Archaeological Science 7: 267-275.

Meeks, N., Craddock, P.T., Geckinli, A., Hook, D., Middleton, A. and Ramage, A., 1996. The scientific study of the refractory remains and gold particles from the Lydin gold refinery at Sardis. Archaeometry '94, ed. S. Demirci, A.M. Özer and G.D. Summers, Ankara, 461-482.

Mohen, J.-P., Nicolardot, J.-P. and Cunisset-Carnot, P., 1971. Une fibule « chypriote " trouvée en Côte-d'Or, , Bulletin de la Société préhistorique française, 68(2): 602-609.

Murray, A.S., Smith A.H. and Walters, H.B., 1900.Excavations in Cyprus, Bequest of Miss E.T. Turner to the BritishMuseum, [London, 1900; reprinted 1970], p. 1-54, pls. I-XII.

Muscarella, O.W., 1965. A fibula from Hasanlu, American $J$ Archaeology 69/3: 233-240.

Myres, J.L., 1914. Handbook of the Cesnola Collection, New York.
Ontalba-Salamanca, M.A., Ager, F.J., Ynsa, M.D., GómezTubío, B.M., Respaldiza, M.A., García López, J., FernándezGómez, F., de la Bandera, M.L. and Grime, G.W., 2001. External microbeam set-up at the CNA (Sevilla) and its application to the study of Tartesic jewellery, Nucl. Instrum. Meth. B 181: 664-669

Ortega-Feliu, I., Gomez-Tubio, B., Ontalba Salamanca, M.A., Respaldiza, M.A., de la Bandera, M.L. and Ovejero ZappINo, G., 2007. Gold and electrum jewellery in the strategic area of Gadir in Phoenician period, Nucl. Instrum. Meth. B 260: 329-335.

PonTe, M.S., 1999. As fibulas do Bronze Final do Norte e Centro de Portugal, Revista de Guimarães II: 539-560.

Ramage, A. and Craddock, P., 2000. King Croesus' Gold. Excavations at Sardis and the History of Gold Refining, London, The British Museum Press.

Salzmann, M., 1863. Bijoux phéniciens trouvés dans la nécropole de Camiros, Revue archéologie VIII, 1-6.

Schliemann, H., 1880. Ilios. The city and country of the Trojan, John Murray, London.

Stronach, D., 1959. The development of the fibula in the Near East, Iraq 21/2: 180-206.

TAIT, H., 2006. 7000 years of jewellery, London, British Museum. 